Bull. Chem. Soc. Ethiop. 2014, 28(1), 111-120.

Printed in Ethiopia

ISSN 1011-3924

DOI: http://dx.doi.org/10.4314/bcse.v28i1.13

(C) 2014 Chemical Society of Ethiopia

\title{
SYNTHESIS, CHARACTERIZATION AND DENSITY FUNCTIONAL THEORY INVESTIGATIONS OF MONOACYL ANILINE DERIVATIVES
}

\author{
Abdullah G. Al-Sehemi ${ }^{1,2^{*}}$, Reem Saied A. A. Al-Amri ${ }^{1}$ and Ahmad $\operatorname{Irfan}^{1 *}$ \\ ${ }^{1}$ Department of Chemistry, Faculty of Science, King Khalid University, Abha 61413, P.O. Box \\ 9004, Saudi Arabia \\ ${ }^{2}$ Unit of Science and technology, Faculty of Science, King Khalid University, Abha 61413, P.O. \\ Box 9004, Saudi Arabia
}

(Received December 27, 2012; revised June 8, 2013)

\begin{abstract}
We synthesized a number of aniline derivatives containing acyl groups to compare their barriers of rotation around the $\mathrm{N}-\mathrm{CO}$ groups. Geometry optimization for all the rotamers have been performed using density functional theory (DFT) at the B3LYP/6-31G** level of theory. For each stationary point we carried out vibrational frequency calculations at the same level to characterize their nature as minima or transition states. The methoxy group substituent on the benzene ring causes some changes in the $\mathrm{C}-\mathrm{C}$ bond distances. We carried out potential energy surface scanning to find out all possible low-energy conformations, which would be used as the initial structure for further molecular calculations. There were only three kinds of conformations with local minimum potential energy and two transition states. The optimized bond lengths and bond angles are in better agreement with the experimental values.
\end{abstract}

KEY WORDS: Monoacyl aniline, Synthesis, Density functional theory, Rotation barrier

\section{INTRODUCTION}

Developments in the field of stereochemistry began in the nineteenth century. The concept of chirality was first introduced in 1815 by the French chemist Jean Baptiste Biot when he discovered optical activity in nature [1]. One of his students, Louis Pasteur achieved the first separation of enantiomers in 1948, he manually resolved a racemic mixture of a tartaric acid salt based on differently shaped crystals [2].

Since then, chirality has become of tremendous importance in our daily life. The chiral element is most usually a chiral center or, as it is sometimes called, a sterogenic center in the molecule which is an atom (usually carbon) bearing four different substituent [3]. Electronaccepting groups are supposed to increase the rotation energy barrier in contrast to electrondonating groups. The influence of the resonance and the field effect of amino and nitro groups on the electron density in the phenyl ring and the respective accelerating and decelerating effects on the rate of enantiomeriazation of atropisomerc biphenyls has been investigated [4]. Amide barriers to rotation have been studied extensively [5]. Clayden and co-workers [6] determined the barriers to rotation about the $\mathrm{Ar}-\mathrm{CO}$ and $\mathrm{N}-\mathrm{CO}$ bonds of naphthoyl amides. The amide is a particularly important functional group in biological and medicinal chemistry and is the means by which polypeptides and hence proteins are assembled. Recently, a number of studies have been carried out to shed light on the properties of interest [7].

In this work we will deal the molecules in which the element of chirality is an axis. An axis of chirality results from the non-planar arrangement of four groups about an axis. We have synthesized the monoacyl aniline derivatives and then investigated the rotation barrier by means of density functional theory.

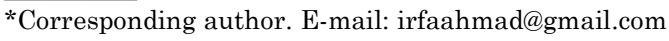




\section{EXPERIMENTAL}

\section{General experimental procedure}

We prepared a number of aniline derivatives containing acyl groups to compare their barriers of rotation around the $\mathrm{N}-\mathrm{CO}$ groups. The general route for the synthesis of mono-aniline derivative is shown in Scheme 1. In general monoacylation of the aniline with acid chloride and pyridine proceeded in high yields and most of the products monoacylaniline were crystalline; with short reaction times and absence of excess acid chloride, formation of diacylation products was not competitive.

${ }^{1} \mathrm{H}$ and ${ }^{13} \mathrm{C}$ nuclear magnetic resonance (NMR) spectra were recorded on a Bruker (ARX500 spectrometer at $500 \mathrm{MHz}$ and $125 \mathrm{MHz}$, respectively) at room temperature in deuterochloroform $\left(\mathrm{CDCl}_{3}\right)\left(\mathrm{CH}_{3} \mathrm{Cl} \delta 7.26\right.$ singlet) at $500 \mathrm{MHz}$ and deuterated dimethyl sulfoxide (DMSO-d $\left.\mathrm{d}_{6}\right)\left(\mathrm{CH}_{3} \mathrm{SOC}_{3} \delta 2.52\right.$ singlet) at $500 \mathrm{MHz}$ unless other wise stated. ${ }^{13} \mathrm{C}$ NMR spectra were recorded on DRX-500 (125 MHz). Infrared (IR) spectra of crystalline compounds were determined using Nujol mulls and of liquids either in dichloromethane or chloroform solutions or neat on a JASCO FTIR-460 Plus spectrophotometer. Melting points (mps) were determined with a Bi/Bornsted electrothermal. Mass spectra were determined using a Kratos Concept mass spectrometer using electron impact (EI), chemical ionization (CI) or fast atom bombardment (FAB). Dichloromethane was distilled from calcium hydride and stored over $4 \AA$ molecular sieves.

\section{Physical data}

For nuclear magnetic resonance (NMR) spectra, chemical shifts and expressed in ppm on the $\delta$ scale relative to the internal standard (TMS). The following abbreviations are used s-singlet, $t-$ triplet, q-quartet, d-doublet, h-heptet, m-multiplet, dd-doublet of doublets, ddd-doublet of doublet of doublet, dq-doublet of quartets, br-broad; $J$ is the coupling constant $(\mathrm{Hz})$. Assignment of ${ }^{13} \mathrm{C}$ signals was assisted by using DEPT. For intensity of infra-red (IR) spectra peaks, abbreviations used are: s-strong, m-medium, w-weak, br-broad. Mass spectra were determined in units of mass relative to change $(\mathrm{m} / \mathrm{z})$.

General procedure for mono-acylation of aniline derivatives MAA (2)

To a stirred solution of the aniline derivatives $(2 \mathrm{~g})$ in dichloromethane was added pyridine (1.2 eq.) followed by drop wise addition of the acid chloride (1.2 eq.). After $24 \mathrm{~h}$, further dichloromethane $(10 \mathrm{~mL})$ was added, the solution then washed successively with saturated aqueous sodium hydrogen carbonate, hydrochloric acid ( $2 \mathrm{M})$, water, then dried and the solvent removed under reduced pressure to give the monoacyl aniline MAA (2), see Scheme 1.

\section{$N$-(2-methoxyphenyl)acetamide MAA (2a)}

The general procedure for the $\mathrm{N}$-acylation of aniline derivative was followed using 2-methoxy aniline ( $2 \mathrm{~g}, 16.2 \mathrm{mmol})$, pyridine $(1.54 \mathrm{~g}, 19.5 \mathrm{mmol})$ and acetyl chloride $(1.53 \mathrm{~g}, 19.5 \mathrm{mmol})$. After work-up, $\mathrm{N}$-(2-methoxyphenyl) acetamide was obtained as a white needle crystals from ethanol, yield 1.9 g, $71 \%$, m.p. 83-86 ${ }^{\circ} \mathrm{C},{ }^{1} \mathrm{H}$ NMR $\left(\mathrm{CDCl}_{3}\right) \delta 2.19\left(3 \mathrm{H}, \mathrm{s}, \mathrm{C}_{3} \mathrm{CO}\right), 3.86(3 \mathrm{H}, \mathrm{s}$, $\left.\mathrm{OCH}_{3}\right), 6.86,6.94$, and 7.05 [3H, m, C$\left.(\mathrm{Ar})\right], 7.85$ [1H, br s, 6-CH (Ar)], $8.34(1 \mathrm{H}, \mathrm{s}, \mathrm{N} \underline{\mathrm{H}})$; ${ }^{13} \mathrm{C}$ NMR $\left(\mathrm{CDCl}_{3}, 125 \mathrm{MHz}\right) \delta 24.82\left(\underline{\mathrm{CH}}_{3} \mathrm{CO}\right), 55.63\left(\mathrm{OCH}_{3}\right), 109.94$ [3- $\left.\underline{\mathrm{CH}}(\mathrm{Ar})\right], 119.87$ [6$\underline{\mathrm{CH}}(\mathrm{Ar})], 120.98$ [5- $\underline{\mathrm{CH}}(\mathrm{Ar})], 127.69$ [4- $\underline{\mathrm{CH}}(\mathrm{Ar})], 147.80(\mathrm{C}=\underline{\mathrm{C}}-\mathrm{O})$ and $168.9(\underline{\mathrm{CO}})$. 
N-(2-Methoxy-phenyl)-4-nitro-benzamide MAA (2b)

The general procedure for the $\mathrm{N}$-acylation of aniline derivative was followed using 2-methoxy aniline (2 g, $16.2 \mathrm{mmol})$, pyridine (1.54 g, $19.5 \mathrm{mmol})$ and 4-nitrobenzoyl chloride (3.62 g, 19.5 mmol). After work-up, N-(2-methoxy-phenyl)-4-nitro-benzamide was obtained as a yellow crystals shiny, yield $4 \mathrm{~g}, 91 \%$, m.p. $135-139{ }^{\circ} \mathrm{C},{ }^{1} \mathrm{H} \mathrm{NMR}\left(\mathrm{CDCl}_{3}\right) \delta 3.96\left(3 \mathrm{H}, \mathrm{s}, \mathrm{OCH}_{3}\right), 6.97$, 7.13, 7.15 and $8.07[4 \mathrm{H}, \mathrm{m}, \mathrm{C} \underline{\mathrm{H}}(\mathrm{Ar})], 8.07,8.53,8.49$ and $8.50[4 \mathrm{H}, \mathrm{m}, \mathrm{C} \underline{\mathrm{H}}(\mathrm{Ar})]$ and $8.59(1 \mathrm{H}$, $\mathrm{s}, \mathrm{N} \underline{\mathrm{H}}) ;{ }^{13} \mathrm{C} \mathrm{NMR}\left(\mathrm{CDCl}_{3}, 125 \mathrm{MHz}\right) \delta 55.89\left(\mathrm{OCH}_{3}\right), 110.1,120.03,121.24,123.98,123.98$, 124.73 and 127.1 [ $8 \times \underline{\mathrm{CH}}(\mathrm{Ar})], 128.24$ [ $2 \times \underline{\mathrm{CN}}(\mathrm{Ar})], 140.73$ [C=C $-\mathrm{O}(\mathrm{Ar})], 148.26$ [COC $(\mathrm{Ar})]$, $149.76\left[\underline{C N O}_{2}(\mathrm{Ar})\right]$ and 163.07 (CO); IR v/cm ${ }^{-1}: 3321(\mathrm{~N}-\mathrm{H}), 1647(\mathrm{C}=\mathrm{O}), 1341(\mathrm{C}-\mathrm{O}-\mathrm{C})$.

N-(2-Methoxy-phenyl)-4-bromo-benzamide MAA (2c)

The general procedure for the $\mathrm{N}$-acylation of of aniline derivative was followed using 2methoxy aniline (2 g, $16.2 \mathrm{mmol})$, pyridine (1.54 g, $19.5 \mathrm{mmol})$ and 4-bromobenzoyl chloride (4.28 g, $19.5 \mathrm{mmol})$. After work-up, $\mathrm{N}$-(2-methoxy-phenyl)-4-bromo-benzamide was obtained as a white crystals shiny, yield $4.4 \mathrm{~g}, 89 \%$, m.p. $127-131^{\circ} \mathrm{C},{ }^{1} \mathrm{H} \mathrm{NMR}\left(\mathrm{CDCl}_{3}\right) \delta 3.39(3 \mathrm{H}, \mathrm{s}$, $\left.\mathrm{OCH}_{3}\right), 6.94[1 \mathrm{H}, \mathrm{dd}, J 8.2,2.0, \mathrm{CH}(\mathrm{Ar})], 7.04$ [1H, ddd, $\left.J 12.2,8.2,2.0, \mathrm{CH}(\mathrm{Ar})\right], 7.11$ [1H,

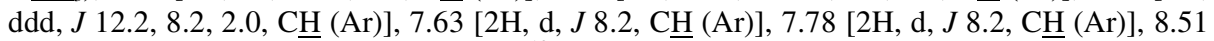
$[1 \mathrm{H}$, br s, $\mathrm{C} \underline{\mathrm{H}}(\mathrm{Ar})]$ and $8.53(1 \mathrm{H}, \mathrm{s}, \mathrm{N} \underline{\mathrm{H}}) ;{ }^{13} \mathrm{C} \mathrm{NMR}\left(\mathrm{CDCl}_{3}, 125 \mathrm{MHz}\right) \delta 55.85\left(\mathrm{OCH}_{3}\right), 110.01$, 119.93, 121.20, 24.16, 126.41, 127.54, 127.54 and 131.98 [8× $\underline{\mathrm{CH}}$ (Ar)], 131.98, 134.13 and $134.13[3 \times \mathrm{C}=\mathrm{C}(\mathrm{Ar})], 148.19\left(\mathrm{COCH}_{3}\right)$ and $164.22(\mathrm{CO}) ; \mathrm{IR} v / \mathrm{cm}^{-1}: 3409(\mathrm{~N}-\mathrm{H}), 1667(\mathrm{C}=\mathrm{O})$, 1341 (C-O-C); MS m/z (\%): 309 ( $\left.\mathrm{M}^{+2}, 11\right), 307\left(\mathrm{M}^{+}, 12\right), 183$ (100), 155 (38), 104 (21), 76 (37), 50 (24).

\section{4-Nitro-N-o-tolyl-benzamide MAA (2d)}

The general procedure for the $\mathrm{N}$-acylation of of aniline derivative was followed using 2-methyl aniline ( $2 \mathrm{~g}, 18.7 \mathrm{mmol})$, pyridine $(1.77 \mathrm{~g}, 22.4 \mathrm{mmol})$ and 4-nitro benzoyl chloride $(4.16 \mathrm{~g}$, $22.4 \mathrm{mmol}$ ). After work-up, 4-nitro-N-o-tolyl-benzamide was obtained as a pale yellow crystals shiny, yield 4.3 g, $90 \%$, m.p. $157-160{ }^{\circ} \mathrm{C},{ }^{1} \mathrm{H}$ NMR $\left(\mathrm{CDCl}_{3}\right) \delta 2.34\left(3 \mathrm{H}\right.$, br s, $\left.\mathrm{CH}_{3}\right), 7.32-8.03$ $[8 \mathrm{H}$, br m, $\mathrm{CH}(\mathrm{Ar})]$ and $8.30(1 \mathrm{H}, \mathrm{s}, \mathrm{NH}) ;{ }^{13} \mathrm{C} \mathrm{NMR}\left(\mathrm{CDCl}_{3}, 125 \mathrm{MHz}\right) \delta 17.86\left(\underline{\mathrm{CH}}_{3}\right),(\underline{\mathrm{CH}}-\mathrm{Ar}-$ $\left.\mathrm{NO}_{2}, \mathrm{C}-3.5\right), 123.9,126.45,126.93,128.39$ and 130 [8 $\left.\times \underline{\mathrm{C}} \mathrm{H}(\mathrm{Ar})\right], 130.42[\underline{\mathrm{C}}=\overline{\mathrm{C}}(\mathrm{Ar})], 135.0$ $(\mathrm{C}=\underline{\mathrm{C}}-\mathrm{NH}), 140.33(\mathrm{C}=\underline{\mathrm{C}}-\mathrm{CO}), 149.72\left(\mathrm{C}=\underline{\mathrm{C}}-\mathrm{NO}_{2}\right)$ and $163.99(\underline{\mathrm{CO}})$.

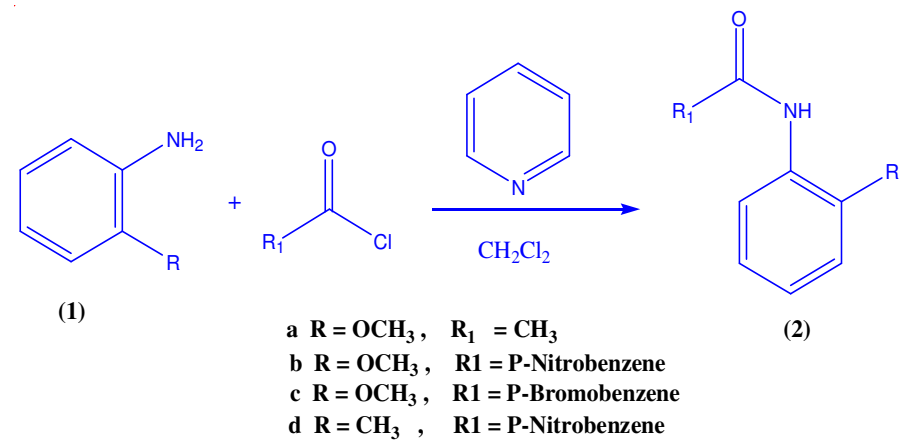

Scheme 1. The schematic diagram of synthesized compounds $\mathbf{2 a - 2 d . ~}$ 


\section{COMPUTATIONAL DETAILS}

Density functional theory (DFT) calculations of the rotational barrier of six 3-(o-aryl)-5-methylrhodanines were carried out by Yeliz Aydeniz et al. They found good agreement with the available experimental results [8]. Geometry optimization for all the rotamers have been performed using density functional theory (DFT) at the B3LYP functional and $6-31 \mathrm{G}^{* *}$ basis set which has been proved to be an excellent method [9-12]. Moreover, B3LYP/6-31G(d,p) level is adequate which has been applied to computed the different properties and successfully reproduce the experimental data previously [13]. Recently, rotational energy barrier for quinazolinone derivatives has been computed at different levels of theory B3LYP/6-31G**, PM3, AM1, MNDO, HF/6-31G* and found that AM1 is rational and reasonable approach which reproduce the experimental data (details can be found in reference 14). In the present study, we have optimized the geometries at B3LYP/6-31G** and B3LYP/6-31+G** level of theories. We have also applied AM1 method. We found that basis set has no significant effect thus we focused on B3LYP/6-31G** and B3LYP/6-31G** level of theory.

\section{RESULTS AND DISCUSSION}

\section{Geometrical parameters}

The optimized structures of the aniline derivatives (2a-d) for the most stable conformer with labelling are presented in Figure 1. The experimental and optimized geometric parameters (bond lengths, bond angles and dihedral angles) have been listed in Table 1. The theoretical results are comparable with the reported structural parameters of related molecules [15-19].

The calculated values are in good agreement with the experimental values. The experimental results were obtained at solid phase and the theoretical calculations at gaseous phase. The experimental crystallographic parameters and the predicted bond lengths and bond angles of the four compounds MAA (2a-d) of minimum energy were compared by linear regressional analysis. The statistical results of the linear dependence between the experimental X-ray versus the predicted bond lengths and of the experimental X-ray versus predicted bond angles and dihedral angle are presented in Figures 2.

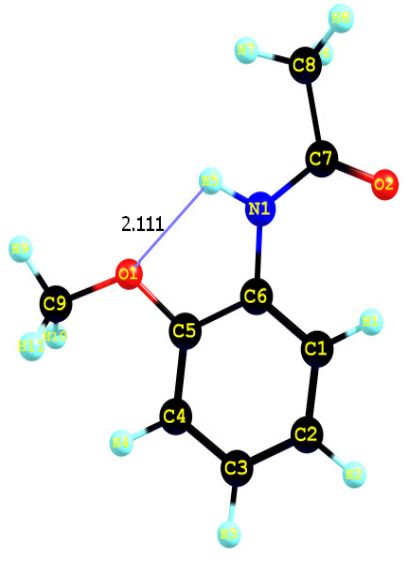

(2a)

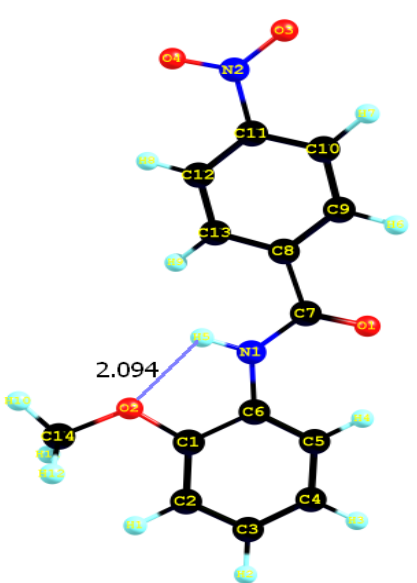

(2b)

Bull. Chem. Soc. Ethiop. 2014, 28(1) 


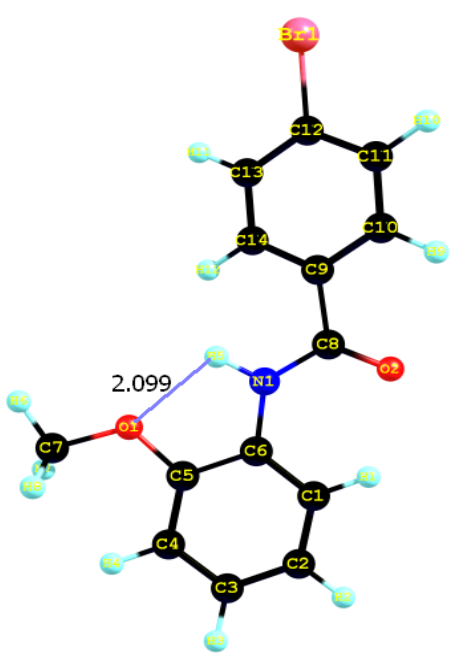

(2c)

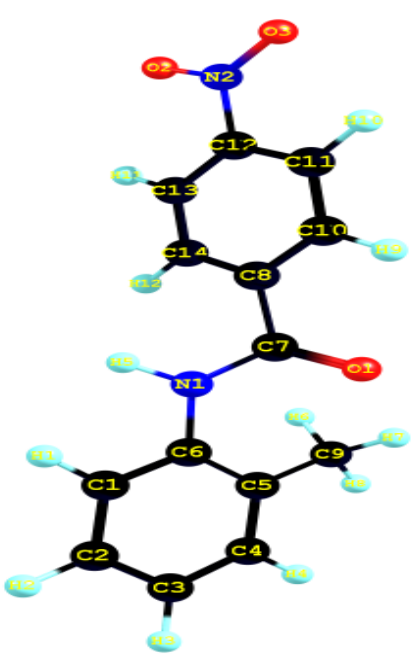

(2d)

Figure 1. Optimized geometries at B3LYP/6-31G** level of theory of the studied aniline derivatives (2a-d) for the most stable conformers, showing intermolecular H-bond (in $\AA$ ).

Table 1. Optimized geometrical parameters (bond lengths $(\AA)$, bond angles and dihedral angles (degrees) at B3LYP/6-31G** level of theory.

\begin{tabular}{|c|c|c|c|c|c|}
\hline Parameters & $2 a$ & $2 \mathbf{b}$ & $2 \mathrm{c}$ & $2 d$ & X-ray \\
\hline \multicolumn{6}{|c|}{ Bond lengths } \\
\hline $\mathrm{C} 1-\mathrm{C} 2$ & 1.398 & 1.398 & 1.398 & 1.392 & 1.401 \\
\hline C1-C6 & 1.397 & 1.397 & 1.397 & 1.400 & 1.399 \\
\hline C1-H1 & 1.081 & 1.081 & 1.081 & 1.088 & \\
\hline $\mathrm{C} 2-\mathrm{C} 3$ & 1.391 & 1.391 & 1.391 & 1.395 & 1.393 \\
\hline $\mathrm{C} 2-\mathrm{H} 2$ & 1.086 & 1.086 & 1.086 & 1.086 & \\
\hline $\mathrm{C} 3-\mathrm{C} 4$ & 1.400 & 1.400 & 1.400 & 1.394 & 1.399 \\
\hline C3-H3 & 1.086 & 1.086 & 1.086 & 1.086 & \\
\hline C4-C5 & 1.392 & 1.392 & 1.392 & 1.402 & 1.399 \\
\hline C4-H4 & 1.084 & 1.084 & 1.084 & 1.087 & \\
\hline C5-C6 & 1.416 & 1.416 & 1.416 & 1.408 & 1.404 \\
\hline C5-O1 & 1.376 & 1.374 & 1.375 & & 1.371 \\
\hline C5-C10 & & & & 1.507 & \\
\hline C6-N1 & 1.407 & 1.408 & 1.407 & 1.428 & 1.424 \\
\hline N1-C7 & 1.375 & 1.371 & 1.374 & 1.379 & 1.343 \\
\hline $\mathrm{N} 1-\mathrm{H} 5$ & 1.011 & 1.011 & 1.011 & 1.012 & \\
\hline C7-C8 & 1.523 & 1.509 & 1.505 & 1.508 & 1.508 \\
\hline $\mathrm{C} 7-\mathrm{O} 2$ & 1.224 & 1.227 & 1.228 & 1.224 & 1.244 \\
\hline O1....H5 & 2.111 & 2.094 & 2.099 & & \\
\hline & \multicolumn{5}{|c|}{ Bond angles } \\
\hline $\mathrm{C} 1-\mathrm{C} 2-\mathrm{C} 3$ & 120.6 & 120.6 & 120.6 & 119.4 & 119.6 \\
\hline $\mathrm{C} 1-\mathrm{C} 2-\mathrm{H} 2$ & 119.1 & 119.1 & 119.1 & 119.9 & 120.2 \\
\hline
\end{tabular}

Bull. Chem. Soc. Ethiop. 2014, 28(1) 


\begin{tabular}{|c|c|c|c|c|c|}
\hline C1-C6-C5 & 119.2 & 119.4 & 119.2 & 120.8 & 119.9 \\
\hline C1-C6-N1 & 124.7 & 124.8 & 124.9 & 117.8 & 122.9 \\
\hline C2-C1-C6 & 120.0 & 119.8 & 119.9 & 120.7 & 120.1 \\
\hline $\mathrm{C} 2-\mathrm{C} 1-\mathrm{H} 1$ & 121.4 & 121.3 & 121.3 & 120.2 & 120.0 \\
\hline C2-C3-C4 & 120.0 & 120.1 & 120.1 & 119.7 & 120.8 \\
\hline $\mathrm{C} 2-\mathrm{C} 3-\mathrm{H} 3$ & 120.6 & 120.5 & 120.6 & 120.4 & 119.6 \\
\hline $\mathrm{C} 3-\mathrm{C} 2-\mathrm{H} 2$ & 120.2 & 120.3 & 120.2 & 120.7 & 120.2 \\
\hline C3-C4-C5 & 119.7 & 119.7 & 119.7 & 122.1 & 119.5 \\
\hline C3-C4-H4 & 119.8 & 119.9 & 119.9 & 119.5 & 120.2 \\
\hline C4-C3-H3 & 119.4 & 119.3 & 119.4 & 119.9 & 119.6 \\
\hline C4-C5-C6 & 120.5 & 120.4 & 120.5 & 117.3 & 120.0 \\
\hline C4-C5-O1 & 124.8 & 124.9 & 124.9 & & 125.0 \\
\hline C4-C5-C9 & & & & 120.3 & \\
\hline C5-C4-H4 & 120.4 & 120.4 & 120.4 & 118.3 & 120.2 \\
\hline C5-C6-N1 & 116.1 & 115.8 & 115.9 & 121.4 & 117.1 \\
\hline C5-O1-C9 & 118.3 & 118.4 & 118.4 & & 116.7 \\
\hline C6-C5-O1 & 114.8 & 114.7 & 114.7 & & 115.0 \\
\hline C6-C5-C9 & & & & 122.3 & \\
\hline C6-C1-H1 & 118.6 & 118.9 & 118.8 & 119.1 & 120.0 \\
\hline C6-N1-C7 & 128.7 & 128.5 & 128.6 & 124.6 & 126.7 \\
\hline C6-N1-H5 & 113.7 & 113.3 & 113.4 & 115.4 & 107.0 \\
\hline N1-C7-C8 & 114.3 & 114.8 & 115.0 & 115.2 & 115.5 \\
\hline $\mathrm{N} 1-\mathrm{C} 7-\mathrm{O} 2$ & 124.3 & 124.5 & 124.0 & 123.6 & 124.7 \\
\hline C7-N1-H5 & 117.7 & 117.9 & 117.8 & 116.1 & 126.0 \\
\hline $\mathrm{C} 8-\mathrm{C} 7-\mathrm{O} 2$ & 121.4 & 120.7 & 121.0 & 121.2 & 119.7 \\
\hline O1-C9-H9 & 106.0 & 106.0 & 106.0 & & 109.5 \\
\hline O1-C9-H10 & 111.4 & 111.3 & 111.3 & & 109.5 \\
\hline O1-C9-H11 & 111.4 & 111.3 & 111.3 & & 109.5 \\
\hline Parameters & $2 \mathbf{a}$ & $2 \mathbf{b}$ & $2 c$ & 2d & X-ray \\
\hline \multicolumn{6}{|c|}{ Dihedral angles } \\
\hline $\mathrm{C} 1-\mathrm{C} 2-\mathrm{C} 3-\mathrm{C} 4$ & 0.001 & 0.022 & 0.017 & -0.938 & -1.000 \\
\hline $\mathrm{C} 1-\mathrm{C} 2-\mathrm{C} 3-\mathrm{H} 3$ & -180.0 & -180.0 & -179.9 & 179.6 & \\
\hline C1-C6-C5-C4 & 0.001 & 0.080 & 0.051 & -1.643 & -2.000 \\
\hline C1-C6-C5-O1 & -180.0 & -179.9 & $\begin{array}{l}-179.9 \\
\end{array}$ & & 177.9 \\
\hline C1-C6-C5-C9 & & & & 177.2 & \\
\hline C1-C6-N1-C7 & 0.031 & -2.846 & -2.812 & 120.7 & 29.10 \\
\hline C1-C6-N1-H5 & 180.0 & -177.5 & -177.5 & -36.14 & \\
\hline C2-C1-C6-C5 & 0.000 & -0.038 & 0.001 & 0.799 & 1.300 \\
\hline C2-C1-C6-N1 & 180.0 & -179.5 & -179.5 & 177.8 & 178.0 \\
\hline $\mathrm{C} 2-\mathrm{C} 3-\mathrm{C} 4-\mathrm{C} 5$ & 0.000 & 0.021 & 0.034 & 0.041 & 0.400 \\
\hline C2-C3-C4-H4 & -180.0 & 179.9 & 179.9 & -178.9 & \\
\hline C3-C2-C1-C6 & -0.001 & -0.013 & -0.034 & 0.524 & 0.100 \\
\hline C3-C2-C1-H1 & 180.0 & 179.8 & 179.7 & -178.6 & \\
\hline C3-C4-C5-C6 & -0.001 & -0.072 & -0.068 & 1.236 & 1.100 \\
\hline C3-C4-C5-O1 & 180.0 & 179.9 & 179.9 & & -178.8 \\
\hline C3-C4-C5-C9 & & & & -177.6 & \\
\hline $\mathrm{C} 4-\mathrm{C} 3-\mathrm{C} 2-\mathrm{H} 2$ & -180.0 & 180.0 & 180.0 & 179.7 & \\
\hline C4-C5-C6-N1 & -180.0 & -179.6 & -179.6 & -178.5 & -178.8 \\
\hline C4-C5-O1-C9 & 0.003 & 1.223 & 1.294 & & 5.600 \\
\hline $\mathrm{C} 5-\mathrm{C} 4-\mathrm{C} 3-\mathrm{H} 3$ & -180.0 & 180.0 & 180.0 & 179.5 & \\
\hline C5-C6-C1-H1 & 180.0 & -179.8 & -179.7 & 179.9 & \\
\hline C5-C6-N1-C7 & -180.0 & -177.6 & -177.7 & -62.40 & -154.1 \\
\hline C5-C6-N1-H5 & -0.007 & 2.969 & 2.984 & 140.8 & \\
\hline
\end{tabular}




\begin{tabular}{|l|c|c|c|c|c|}
\hline C6-C1-C2-H2 & 180.0 & -180.0 & -180.0 & 179.9 & \\
\hline C6-C5-C4-H4 & 180.0 & 180.0 & 180.0 & 179.8 & \\
\hline C6-C5-O1-C9 & -180.0 & -178.8 & -178.7 & & -174.3 \\
\hline C6-N1-C7-C8 & 180.0 & 178.8 & 178.3 & -175.6 & 178.3 \\
\hline C6-N1-C7-O2 & -0.021 & -1.838 & 2.317 & 4.625 & 0.800 \\
\hline N1-C6-C1-H1 & -0.002 & 0.685 & 0.788 & -3.127 & \\
\hline N1-C6-C5-O1 & 0.004 & 0.380 & 0.425 & & 1.000 \\
\hline N1-C6-C5-C9 & & & & -3.127 & \\
\hline O2-C7-N1-H5 & 180.0 & 172.6 & 172.2 & 161.3 & \\
\hline
\end{tabular}

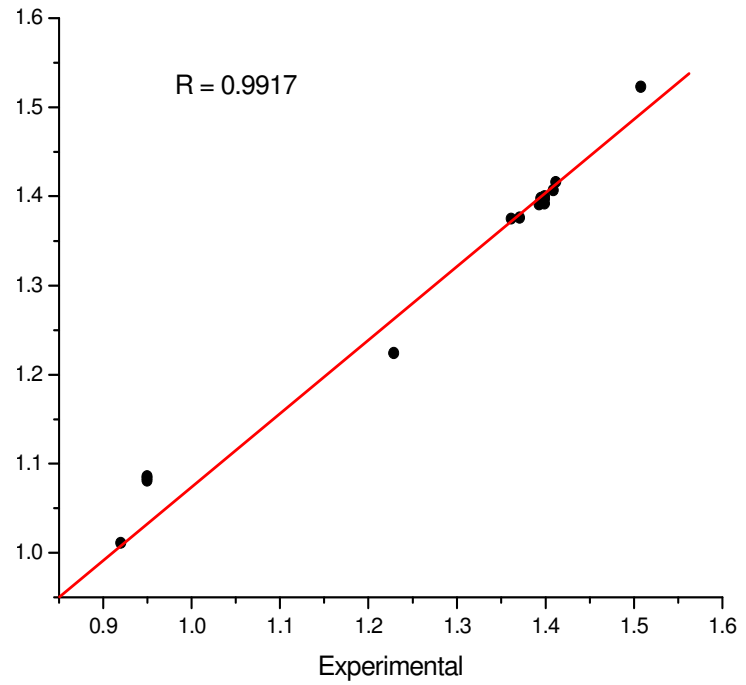

(a)

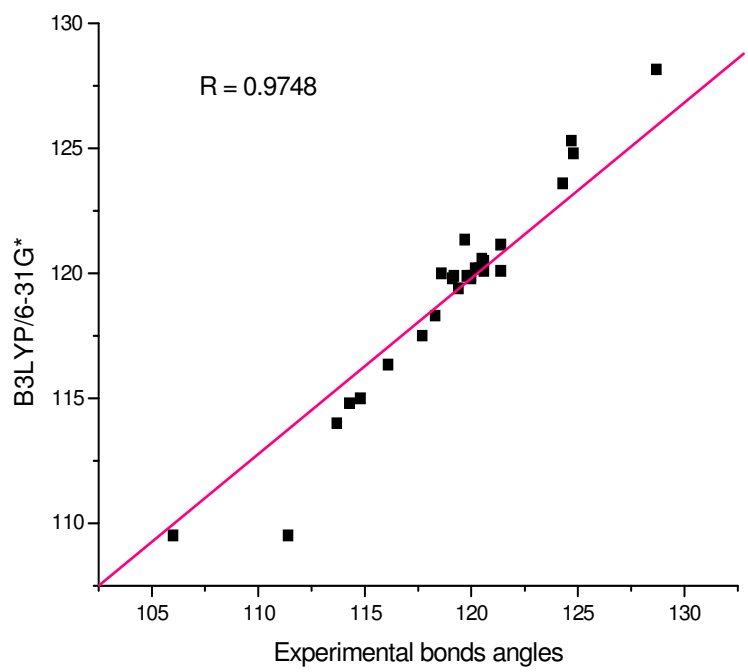

(b)

Bull. Chem. Soc. Ethiop. 2014, 28(1) 


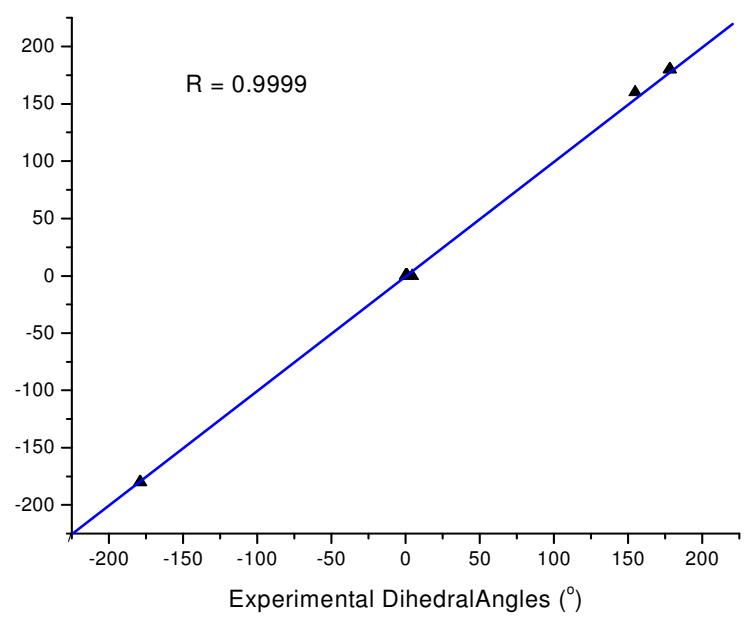

(c)

Figure 2. Correlations between the experimental and theoretical (a) bond lengths ( $\mathrm{A})$, (b) bond angles, and (c) dihedral angles for 2 a obtained at B3LYP/6-31G** level of theory.

The methoxy group on the benzene ring causes some changes in the $\mathrm{C}-\mathrm{C}$ bond distances. Also, their ortho positions play vital role in shaping the structural and electronic properties of the molecules. The methoxy group oxygen shares its loan pair of electrons with the $p$ electrons in a ring and also interacts with the nearby $\pi$ systems. Therefore, the interaction of amide groups with the ortho-substituents enhances intermolecular interaction including $\pi$ - $\pi$ stacking from phenyl groups. The existence of an intermolecular hydrogen bonding between the hydrogen atom of amine and the oxygen atom of the methoxy group ( $\mathrm{N}-\mathrm{H}---\mathrm{O})$, which was confirmed by the short distance found (2.094-2.111 $\AA$ ). The hydrogen bonding is critical in determining the structure stability. In general the hydrogen bond strength is indicated by the length, e.g. shorter hydrogen bonds lengths typically indicate stronger hydrogen bonds and Vice versa.

\section{Barriers to rotation}

Planarity of the amide plane and information about amide bond are the key factors for investigation of the peptide molecules. The dihedral angle between amide moieties with respect to a plane of aromatic ring is important for consideration. It is well known that the conformation is restricted by partial double bond. So, we carried out a further potential energy surface scanning to find out all possible low-energy conformations, which would be used as the initial structure for further molecular calculation and dynamic simulations. MAAs (2a-d) was selected for this purpose. The dihedral angle $(\varphi=\mathrm{C} 5-\mathrm{C} 6-\mathrm{N} 1-\mathrm{C} 7$, for MAA 2a and 2d, C1-C6-N1-C7 for MAA (2b) and C5-C6-N1-C8 of MAA (2c) were subjected to rotate from $180^{\circ}$ to $-180^{\circ}$ with a step of $5^{\circ}$. The energy values in the vertical axis were the relative, which were obtained by all energy values minus the maximum energy value at the dihedral angle. We found that there are four local minimum potential energies, where the torsion angles of the corresponding conformations range $180-150^{\circ}, 55^{\circ},-55^{\circ}$ and -150 to $-180^{\circ}$, respectively. Herein the conformations with torsion angles of 180 to $150^{\circ}$ and -155 to $-180^{\circ}$ were in fact the same. So there were only three kinds of conformations with local minimum potential energy. There are also two transitions states: TS1 where the torsion angles were found to be very close to $0^{\circ}$. The 
TS2 was found to be more stable than TS1 one, which may be due to the electron shell repulsion between electrons pairs of oxygen atoms (Table 2).

Table 2. Computational energy values of TS1 and TS2 corresponding to the dihedral angels of MAAs (2ad).

\begin{tabular}{|c|c|c|c|c|c|c|}
\hline \multirow{2}{*}{$N o$} & $R$ & $R 1$ & \multicolumn{4}{|c|}{$C 10-N 9-N 14-N 15$} \\
\cline { 3 - 6 } & & & $T A\left(^{\circ}\right)$ & $\Delta G T S 1$ & $T A\left(^{\circ}\right)$ & $\Delta G T S 2$ \\
\hline 2a & $\mathrm{OCH}_{3}$ & $\mathrm{CH}_{3}$ & -20 & 8.5 & 0 & 6.9 \\
\hline 2b & $\mathrm{OCH}_{3}$ & $p$-Nitrobenzene & -30 & 10.9 & 0 & 6.9 \\
\hline 2c & $\mathrm{OCH}_{3}$ & $p$-Bromobenzene & -20 & 8.4 & 0 & 6.9 \\
\hline 2d & $\mathrm{CH}_{3}$ & $p$-Nitrobenzene & -25 & 10.5 & 0 & 7.2 \\
\hline
\end{tabular}

TS1 = Transition state $1 ;$ TS2 $=$ Transition state $2 ; \Delta G=$ Enthalpy in $\mathrm{kcal} / \mathrm{mol} ; \mathrm{TA}=$ Torsion angle .

\section{CONCLUSIONS}

The N-(2-methoxyphenyl)acetamide, N-(2-methoxy-phenyl)-4-nitro-benzamide, N-(2-methoxyphenyl)-4-bromo-benzamide, and 4-nitro-N-o-tolyl-benzamidehave been synthesized. The theoretical results obtained are in good agreement with the reported structural parameters and experimental values. The experimental X-ray and the predicted bond lengths and angles were compared by linear regressional analysis. The methoxy group substituent on the benzene ring causes some changes in the $\mathrm{C}-\mathrm{C}$ bond distances. The methoxy group oxygen shares its loan pair of electrons with the $\mathrm{p}$ electrons in a ring and also interacts with the nearby $\pi$ systems. Therefore, the interaction of amide groups with the ortho-substituents enhances intermolecular interaction including $\pi-\pi$ stacking from phenyl groups and also existence of an intermolecular hydrogen bonding between the hydrogen atom of amine and the oxygen atom of the methoxy group. Four local minimum potential energies and two transition states have been observed.

\section{ACKNOWLEDGEMENTS}

We thank King Abdul Aziz city of Science and technology (KACST) for their financial support to Reem Saied Abdulaziz Muhammad Al-Yabess Al-Amri by the grant No. GSP-18-138.

\section{REFERENCES}

1. Biot, J.B. Bull. Soc. Philamoth. Paris 1815, 190.

2. Pasteur, L. Comp. Rend Paris 1884, 26, 535.

3. Mislow, K.; Siegel, J. J. Am. Chem. Soc. 1984, 106, 3319.

4. Roussel, C.; Adjimi, M.; Chemlal, A.D. J. Org. Chem. 1988, 53, 5076.

5. Yoder, C.; Gardner, R. J. Org. Chem. 1981, 46, 64.

6. Ahmed, A.; Bragg, R.A.; Clayden, J.; Lai, L.W.; McCarthy, C.; Pink, J.H.; Westlund, N.; Yasin, S.A. Tetrahedron 1998, 54, 13277.

7. Noolvi, M.N.; Patel, H.M. Arabian J. Chem. 2010, http://dx.doi.org/10.1016/j.arabjc.2010.12.031 (b) Ryu, C.-K.; Kim, Y.H.; Im, H.A.; Kim, J.Y.; Yoon, J.H.; Kim, A. Bioorg. Med. Chem. Lett. 2012, 22, 500. (c) Li, Z.; Tan, J.-H.; He, J.-H.; Long, Y.; Ou, T.-M.; Li, D.; Gu, L.-Q.; Huang, Z.-S. Eur. J. Med. Chem. 2012, 47, 299.

8. Aydeniz, Y.; Oğuz, F.; Yaman, A.; Konuklar, A.S.; Doğan, I.; Aviyente, V.; Klein, R. A. Org. Biomol. Chem. 2004, 2, 2426. 
9. Holdenberg, P.; Kohn, W. Phys. Rev. B 1964, 136, 864.

10. Becke, A.D. J. Chem. Phys. 1993, 98, 5648.

11. Lee, C.; Yang, W.; Parr, R.G. Phys. Rev. B 1988, 37, 785.

12. Stephens, P.J.; Devlin, F.J.; Chabalowski, C.F.; Frisch, M.J. J. Phys. Chem. 1994, 98, 11623. (b) Lynch, B.J.; Fast, P.L.; Harris, M.; Truhlar, D.G. J. Phys. Chem. A 2000, 104, 4811.

13. Chaudhry, A.R.; Ahmed, R.; Irfan, A.; Shaari, A.; Al-Sehemi, A.G. Mater. Chem. Phys. 2013, 138, 468; (b) Al-Sehemi, A.G.; Al-Amri, R.S.A.; Irfan, A. Acta Phys. Chim. Sin. 2013, 29, 1. (c) Irfan, A.; Nadeem, M.; Athar, M.; Kanwal, F.; Zhang, J. Comp. Theo. Chem. 2011, 968, 8. (d) Irfan, A.; Al-Sehemi, A.G.; Muhammad, S.; Zhang, J. Aust. J. Chem. 2011, 64, 1587. (e) Al-Sehemi, A.G.; Irfan, A.; Asiri, A.M. Theor. Chem. Acc. 2012, 131, 1199. (f) Al-Sehemi, A.G.; Al-Melfi, M.A.M.; Irfan, A. Struct. Chem. 2013, 24, 499. (g) Irfan, A.; Al-Sehemi, A.G. J. Mol. Model. 2012, 18, 4893. (h) Jin, R.; Irfan, A. Comput. Theor. Chem. 2012, 986, 93. (i) Irfan, A.; Hina, N.; Al-Sehemi, A.G.; Asiri, A.M. J. Mol. Model. 2012, 18, 4199. (j) Irfan, A.; Al-Sehemi, A.G.; El-Agrody, A.M. J. Mol. Struc. 2012, 1018, 171. (k) Irfan, A.; Ijaz, F.; Al-Sehemi, A.G.; Asiri, A.M. J. Comput. Electron. 2012, 11, 374. (1) Irfan, A.; Zhang, J.; Chang, Y. Theor. Chem. Acc. 2010, 127, 587. (m) Irfan, A.; Cui, R.H.; Zhang, J.P. Theor. Chem. Acc. 2009, 122, 275. (n) Irfan, A.; Al-Sehemi, A.G.; Fouda, A.M. Spectrochim. Acta Part A: Mol. Biomol. Spectr. 2013, 111, 223. (o) Mahmood, A.; Irfan, A. J. Comput. Electron. 2013, DOI 10.1007/s10825-013-0452-0. (p) Irfan, A.; Jin, R.; AlSehemi, A.G.; Asiri, A.M. Spectrochim. Acta Part A: Mol. Biomol. Spectr. 2013, http://dx.doi.org/10.1016/j.saa.2013.02.045.

14. Perdew, J.P.; Chevary, J.A.; Vosko, S.H.; Jackson, K.A.; Pederson, M.R.; Singh, D. J.; Fiolhais C. Phys. Rev. B 1992, 46, 6671.

15. Saeed, A.; Hussain, S.; Bolte, M. Acta Crystal. 2008, E64, o521.

16. Saeed, A.; Hussain, S.; Bolte, M. Acta Crystal. 2008, E64, o603.

17. Xiao, Z.; Ouyang, Y.; Qin, S.; Xie, T.; Yang, J. Acta Crystal. 2010, E66, o67.

18. Saeed, A.; Khera, R. A.; Simpson, J. Acta Crystal. 2010, E66, o214.

19. Saeed, A.; Hussain, S.; Flörke, U. Turk. J. Chem. 2008, 32, 481. 